\title{
Proceedings
}

\section{Technical and Economic Aspects of Stone Pine (Pinus pinea L.) Maintenance in Urban Environments ${ }^{\dagger}$}

\author{
Marcello Biocca*, Pietro Gallo and Giulio Sperandio \\ CREA Consiglio per la ricerca in agricoltura e l'analisi dell'economia agraria. Centro di ricerca Ingegneria e \\ Trasformazioni agroalimentari, via della Pascolare 16, 00015 - Monterotondo (Roma). e-mail@e-mail.com \\ * Correspondence:Correspondence: marcello.biocca@crea.gov.it \\ $+\quad$ Presented at the 1st International Electronic Conference on Forests, 15-30 November 2020; \\ Available online: https://sciforum.net/conference/IECF2020
}

Published: 25 October 2020

\begin{abstract}
The Italian Stone Pine (Pinus pinea L.) is one of the most employed ornamental trees in towns with Mediterranean climates. For example, in the city of Rome, Pinus is the most common genus, with more than 51,000 trees. Due to numerous reasons, the maintenance of this species may constitute a serious issue for the owners. Pruning and felling are the most frequent management operations of trees in towns and this study analyzes the technical and economic features of these operations carried out in 14 work sites (with a total of 25 observed trees). The operations were carried out either with aerial platforms (19 trees) or ascending the crown by tree-climbing (6 trees). The operations were sampled with time studies (12 trees for pruning and 13 for felling). Work time was measured from the beginning of operations to the transport of the residual biomass to the collection and loading point, using centesimal stopwatches and video recording. The total residual biomass was weighed or assessed. Total observation time amounted to 63.1 hours. The evaluation of the costs of each work site considered the fixed and the variable costs and the costs for the labor force. A Multiple Linear Regression modelling was adopted to predict the gross time of the operations. This paper can contribute to optimize trees maintenance methods in urban sites and to assess the potential residual wood biomass attainable from urban forestry maintenance.
\end{abstract}

Keywords: urban forestry; work analysis; residual biomass; pruning costs

\section{Introduction}

The Italian Stone Pine, or Umbrella Pine (Pinus pinea L.) is both a landmark of the Mediterranean coastal areas and an ornamental tree widely used in parks, streets and gardens [1]. For example, according to the data of Rome municipality, in the city of Rome Pinus is the most common genus, with more than 51,000 trees, corresponding to $16.4 \%$ of the total registered trees [2].

With its distinguishing crown shape, Stone Pine contributes to make unique and pictorial the skyline of the city but it was been widely planted especially between the 20 s and 50s of the last century [3], so that a great number of trees are now old or senescent. Various other issues bother this species in town, like the threats deriving from climate change (which undermine the static stability of plants), from new pests and pathogens, from mismanagement (especially road maintenance and management of underground facilities) [4]. Moreover, also pinewoods represent environmental amenity areas at risk, being under siege from intensive urbanization [5]. In this framework the care of pines is very urgent and complex, and a professional approach is needed to manage and maintain trees in towns as well as to protect workers and residents during all phases of these work sites.

Pruning and felling are the most frequent management operations of trees in towns. Pruning is performed throughout the lifetime of an urban tree for various reasons, including: improving growth form, alleviating structural problems (such as removal of deadwood), crown raising, managing pests or diseases, decreasing failure risks and resolving conflicts with infrastructures (buildings, electric cables, road signs and lights, etc.) [6]. An ideal pruning should be operated reducing to a minimum 
the quantity of removed crown, to safeguard the photosynthetic apparatus of the plant and to reduce the operative costs [7]. Felling of senescent, died or hazard trees has increased in the last years for the reasons mentioned above.

Pruning and felling operations can be carried out either utilizing an aerial lift or ascending the crown with ropes, commonly named "tree-climbing". The choice of the employed method largely depends on the accessibility of the tree. Tree-climbing is preferred when targeted and selective interventions on tree branches is demanded and where trees are in confined areas where machinery cannot enter. In urban forestry, tree-climbing is often the only possible solution to maintain trees. The scientific literature about the maintenance operation performed on urban trees by professional arborists seems rather poor. Some authors have studied either safety aspects of the method [8-9], technical approaches [10] or economic aspects [11].

An additional interesting theme related to the maintenance of urban trees is the utilization of the residual biomass, a potentially large and underutilized resource that could exploited at local level for wood products and bio-based fuels for power and heat generation, after the volume has been reduced by chipping [12-18].

The purpose of this study is to investigate the technical and economic features of felling and pruning operation of Stone Pines in urban environment and to evaluate the productivity and costs of the observed yards.

\section{Material and Methods}

This study analyzes works carried out in 14 work sites (with a total of 25 trees observed). The operations were carried out either with aerial platforms (19 trees) or ascending the crown by treeclimbing (6 trees). The felling operations involved 13 trees (observed in 9 yards) (Table 1 ) and the pruning operations 12 trees (observed in 5 yards) (Table 2). In total, 13 work sites were in gardens and parks and one was a tree-lined along a public road. Trunk diameters and heights of trees were measured by means of a tree diameter tape and by a laser rangefinder (mod. TruPulse 360R, Laser Technology Inc), respectively.

The yards showed differences of accessibility and in the ease of carrying out the work. For this aspect, a synthetic qualitative variable named "target", ranging from 1 to 5 , was specifically created. This descriptor indicates the work easiness, especially in relation to the yard's location. A work site scoring " 1 " means that the tree is located close to a busy road, all the big logs must be secured with a rope for their descent, etc. The distance of the trees to the loading point of residual biomass ranged from $1 \mathrm{~m}$ (full accessibility, with the possibility to place a truck for loading very close to the tree) to $40 \mathrm{~m}$ (the collected biomass must be manually transported from the tree to the collection point).

Work time was measured for every operation carried out by a worker during his activity. In particular, five main elements were identified and separated: (1) "setting and stacking" (which includes yard's preparation, transport to the collection point and stacking of residual wood, cleaning of the site), (2) "cutting" (using either manual or motorized tools), (3) "shift" (movement of the operator inside the crown), (4) "delay time for avoidable time losses", (5) "delay time for unavoidable time losses". In this study the time (and the cost) for loading and transportation of the obtained biomass is not considered. The time elements were recorded using centesimal stopwatches and video recording. Five private companies carried out the works, operating both with their own equipment and with rental aerial lifts. The evaluation of the operating costs of each work yard was carried out by means of an analytical method, considering the fixed costs, the variable costs and the costs for the labor force [19]. A Multiple Linear Regression (MLR) modelling was adopted to predict the gross time per tree $\left(\mathrm{h}\right.$ tree $\left.^{-1}\right)$. The statistical analysis of the MLR was performed with the software SPSS [20]. The residual biomass was either assessed by measuring the volume of cut branches stacked at the collection point or weighing the wood with a hanging electronic weighing scale (Laumas, mod. Dten. 500/1). The volume data were converted in fresh weights according to conversion tables [21].

Four values were provided to summarize the data analyses: (1) gross time (h tree-1); (2) biomass productivity $\left.\left(\mathrm{Mg} \mathrm{h}^{-1}\right) ; 3\right)$ hourly cost $\left(€ \mathrm{~h}^{-1}\right) ;(4)$ cost per tree $\left(€\right.$ tree $\left.^{-1}\right)$. 


\section{Results and Discussion}

Table 1 and 2 show dendrometric characteristics of selected trees.

Figure 1 shows the working times of the different work phases of the observed felling and pruning yards. Total observation time amounted to 63.1 hours.

Since the working times appear non-normally distributed data, to assess the differences among work systems and type of operations, the Kruskal-Wallis nonparametric rank test was performed. In general, the yards of felling take around the double time of the pruning ones (4.2 and $2.4 \mathrm{~h} \mathrm{tree}^{-1}$, respectively), resulting statistically significant ( $\mathrm{p}$-value $=0.0001959$. The cutting operation (both in pruning and felling) is the main work time (about 32\% of total work time). Setting and stacking times are greater operating in tree-climbing (average 26.5\%) than with aerial lift (average 17.5\%). This is likely due to the time for wearing personal protective equipment, slings, etc. and to the time needed to launch the throwline, which does not always succeed in the first attempt. Moreover, it resulted decisive the difference in terms of distance from the tree and the collection point, significantly higher in tree-climbing yards than in the aerial lift ones (2 and $18 \mathrm{~m}$, respectively). However, no significant difference was showed comparing the gross operation time between felling and pruning operations ( $\mathrm{p}$-value $=0.6692)$.

Regarding the avoidable delay time, the tree-climbing shows an average of $2.5 \%$ while aerial lift reaches an average of $16.5 \%$. This was probably caused by the limited view of the crown of the lift operator, causing occasionally the platform got stuck in the branches for a while. Moreover, the operator in the aerial lift needs to communicate with the ground workers more often than the treeclimber, in order to place the platform properly. On the contrary, the tree-climber tends to work more autonomously.

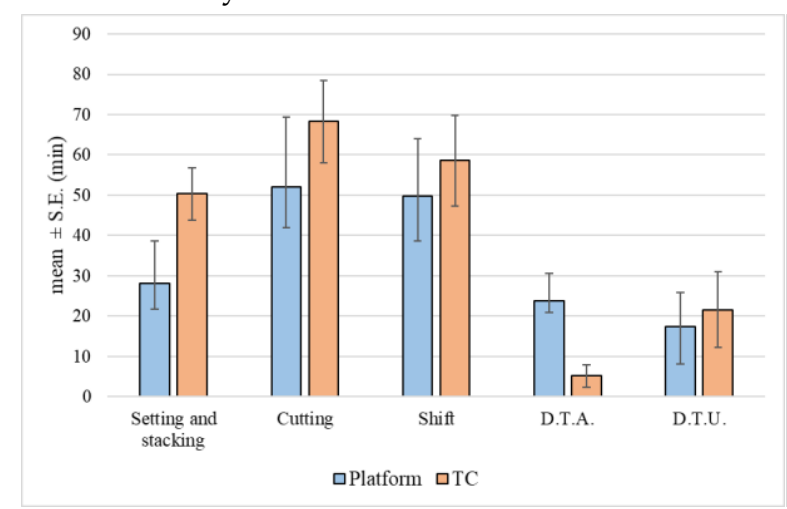

(a)

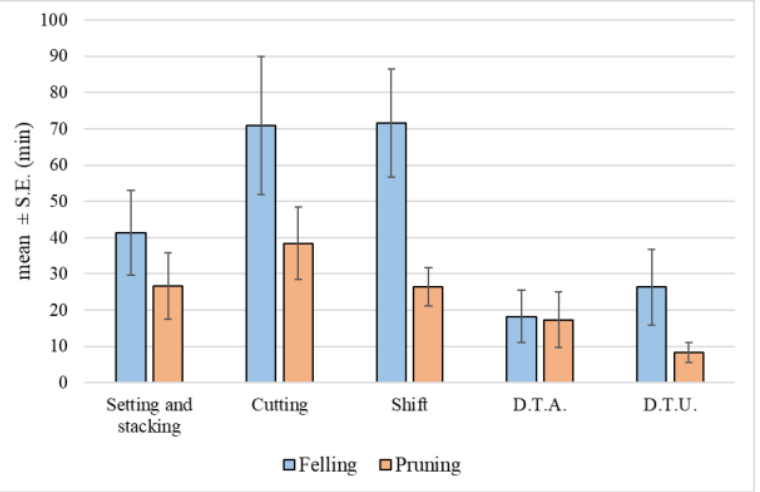

(b)

Figure 1. Total working operation times ( $\min \pm$ standard error), (a) by the operating method and by (b) cultural operation (D.T.A = delay time avoidable; D.T.U. = delay time unavoidable).

Figure 2 summarizes the values of gross time $\left(\mathrm{h}\right.$ tree $\left.{ }^{-1}\right)$, residual biomass productivity $\left(\mathrm{Mg} \mathrm{h}^{-1}\right)$, hourly cost $\left(€ \mathrm{~h}^{-1}\right)$ and cost per tree $\left(€\right.$ tree $\left.^{-1}\right)$, per each combination of work system (aerial lift and treeclimbing) and type of operation (felling and pruning). Obviously, the results are different comparing felling yards with pruning yards. For example, using the aerial lift, the cost per tree of felling is more than six time greater than the cost for pruning (515 and $86 €$ tree $^{-1}$, respectively). This data is largely influenced by two particular yards (AA1 and AA2) that involved the removal of two very large trees (Fig. 6). 
Table 1. Characteristics and results for observed trees in falling yards (D.b.h. = diameter at $1.3 \mathrm{~m}$ from the ground level).

\begin{tabular}{|c|c|c|c|c|c|c|c|c|c|c|c|}
\hline Yard & System & $\begin{array}{c}\text { Height } \\
\text { (m) }\end{array}$ & $\begin{array}{l}\text { D.b.h. } \\
\text { (cm) }\end{array}$ & $\begin{array}{c}\text { Crown diameter } \\
(\mathrm{m})\end{array}$ & $\begin{array}{c}\text { Observed trees } \\
\text { N. }\end{array}$ & $\begin{array}{c}\text { Gross time } \\
\text { h tree } \text { tr }^{-1}\end{array}$ & $\begin{array}{c}\text { Obtained biomass } \\
\mathrm{Mg}\end{array}$ & $\begin{array}{l}\text { Productivity } \\
\qquad \mathrm{Mg} \mathrm{h}^{-1}\end{array}$ & $\begin{array}{c}\text { Unitary time } \\
\text { h tree }{ }^{-1}\end{array}$ & $\begin{array}{c}\text { Hourly cost } \\
€ \mathbf{h}^{-1}\end{array}$ & $\begin{array}{c}\text { Cost per tree } \\
€ \text { tree }^{-1}\end{array}$ \\
\hline FAN & Aerial lift & 20 & 65 & 10 & 3 & 0.74 & 1.60 & 2.18 & 0.46 & 118.3 & 29.0 \\
\hline AA1 & Aerial lift & 27 & 100 & 15 & 1 & 8.08 & 15.00 & 1.86 & 0.54 & 107.9 & 870.9 \\
\hline \multirow[t]{2}{*}{ AA2 } & Aerial lift & 25 & 99 & 12 & 1 & 5.88 & 14.00 & 2.38 & 0.42 & 157.4 & 925.9 \\
\hline & & 19.9 & 81 & 9 & 1 & 0.80 & 3.10 & 3.87 & 0.26 & 62.7 & 50.2 \\
\hline \multirow[t]{2}{*}{ ITA } & Aerial lift & 19.4 & 66 & 11 & 1 & 1.92 & 4.53 & 2.35 & 0.43 & 62.7 & 120.6 \\
\hline & & 18 & 67 & 8 & 1 & 2.58 & 4.98 & 1.93 & 0.52 & 62.7 & 161.7 \\
\hline BUS & Aerial lift & 22 & 67 & 12 & 1 & 8.25 & 5.40 & 0.65 & 1.53 & 77.1 & 635.8 \\
\hline PIG & Tree-climbing & 15 & 60 & 9 & 1 & 3.46 & 1.40 & 0.40 & 2.47 & 97.7 & 337.9 \\
\hline CLS & Tree-climbing & 15 & 42 & 7 & 1 & 1.88 & 0.80 & 0.42 & 2.35 & 37.0 & 69.6 \\
\hline LEM & Tree-climbing & 11 & 49 & 7 & 1 & 2.79 & 1.57 & 0.56 & 1.78 & 59.5 & 166.0 \\
\hline ANA & Tree-climbing & 16 & 80 & 11 & 1 & 5.50 & 4.20 & 0.76 & 1.31 & 44.5 & 245.1 \\
\hline Average & & 18.9 & 71 & 10 & 1.2 & 3.8 & 5.1 & 1.6 & 1.1 & 80.7 & 328.4 \\
\hline
\end{tabular}

Table 2. Characteristics and results for observed trees in pruning yards (D.b.h. = diameter at $1.3 \mathrm{~m}$ from the ground level).

\begin{tabular}{|c|c|c|c|c|c|c|c|c|c|c|c|}
\hline Yard & System & $\begin{array}{c}\text { Height } \\
\text { (m) }\end{array}$ & $\begin{array}{l}\text { D.b.h. } \\
\text { (cm) }\end{array}$ & $\begin{array}{l}\text { Crown diameter } \\
\text { (m) }\end{array}$ & $\begin{array}{c}\text { Observed trees } \\
\text { N. }\end{array}$ & $\begin{array}{c}\text { Gross time } \\
\text { h tree }{ }^{-1}\end{array}$ & $\begin{array}{c}\text { Obtained biomass }^{1} \\
\mathrm{Mg}\end{array}$ & $\begin{array}{c}\text { Productivity } \\
\qquad \mathrm{Mg} \mathrm{h}^{-1}\end{array}$ & $\begin{array}{l}\text { Unitary time } \\
\text { h tree } \\
\text {-1 }\end{array}$ & $\begin{array}{c}\text { Hourly Cost } \\
\qquad \mathbf{h}^{-1}\end{array}$ & $\begin{array}{c}\text { Cost per tree } \\
€ \text { tree }^{-1}\end{array}$ \\
\hline LAT & Aerial lift & 16 & 72 & 14 & 5 & 1.03 & 2.10 & 2.03 & 0.49 & 86.2 & 17.8 \\
\hline \multirow{4}{*}{ ITP } & \multirow{4}{*}{ Aerial lift } & 19 & 67 & 11 & 1 & 0.86 & 0.29 & 0.34 & 2.96 & 52.8 & 45.4 \\
\hline & & 21 & 60 & 10 & 1 & 0.97 & 0.33 & 0.34 & 2.94 & 52.8 & 51.1 \\
\hline & & 19.5 & 66 & 10 & 1 & 1.13 & 0.38 & 0.34 & 2.98 & 52.8 & 59.7 \\
\hline & & 17.2 & 57 & 9 & 1 & 1.60 & 0.43 & 0.27 & 3.71 & 52.8 & 84.1 \\
\hline ENE & Aerial lift & 19.8 & 79 & 14 & 1 & 3.28 & 1.44 & 0.44 & 2.27 & 54.6 & 178.9 \\
\hline INF & Tree-climbing & 15.4 & 74 & 12 & 1 & 3.19 & 0.90 & 0.28 & 3.55 & 46.7 & 149.1 \\
\hline MAG & Tree-climbing & 22 & 70 & 13 & 1 & 3.56 & 1.00 & 0.28 & 3.56 & 36.7 & 130.6 \\
\hline Average & & 18.7 & 68 & 12 & 1.5 & 2.0 & 0.9 & 0.5 & 2.8 & 54.4 & 89.6 \\
\hline
\end{tabular}




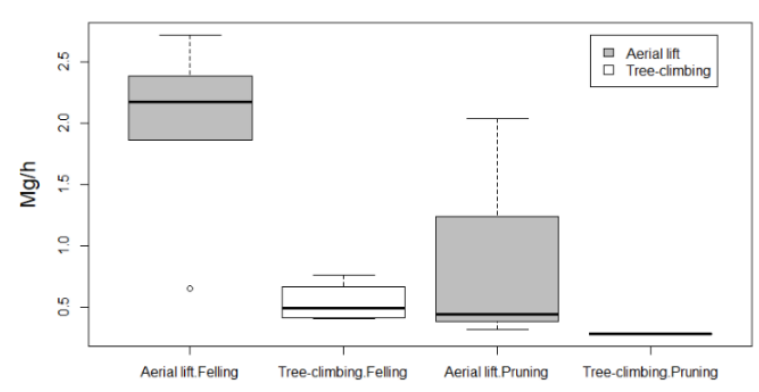

(a)

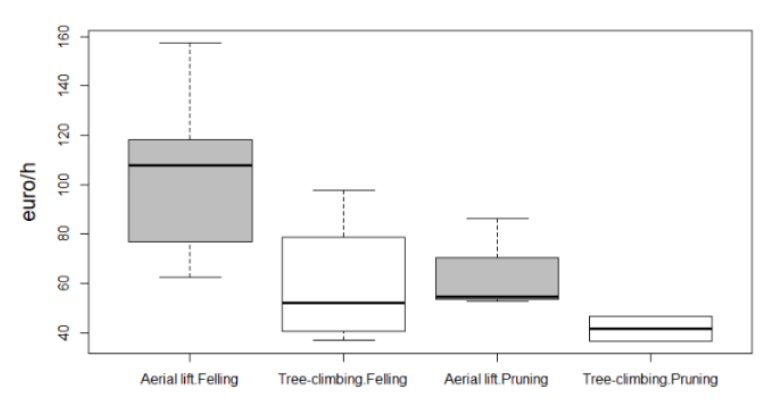

(c)

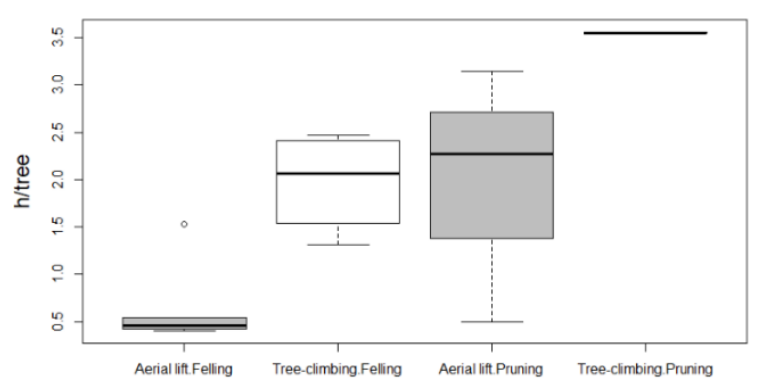

(b)

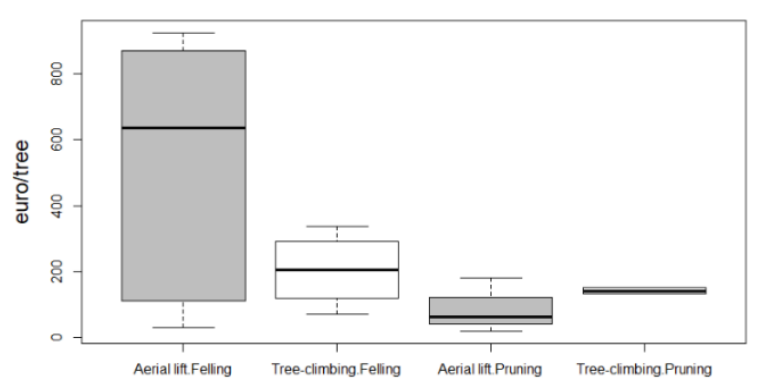

(d)

Figure 2. Distribution values of systems by work operations in the 14 observed yards. (a) Productivity $\left(\mathrm{Mg} \mathrm{h}^{-1}\right)$; (b) gross time (h tree $\left.{ }^{-1}\right)$; (c) hourly cost $\left(€ \mathrm{~h}^{-1}\right)$; (d) unitary cost (€ tree $\left.{ }^{-1}\right)$. Sample size (n): aerial lift by felling: $n=5$; tree-climbing by felling: $n=4$; aerial lift by pruning: $n=3$; tree-climbing by pruning: $\mathrm{n}=2$ (box limits represent: 25 and 75 percentiles; line within box: median; whisker ends: minimum and maximum; circles outside the box: outliers).

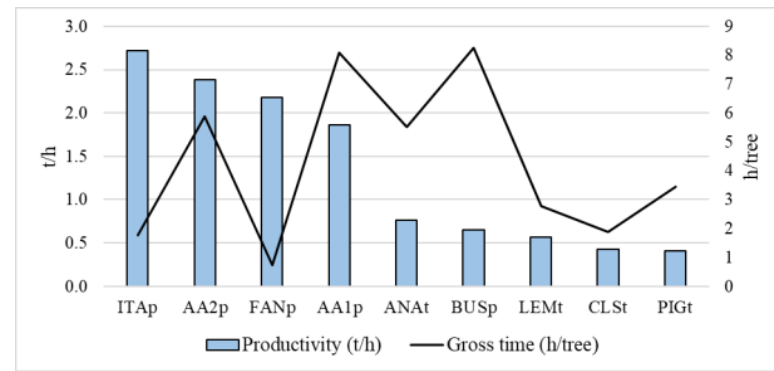

(a)

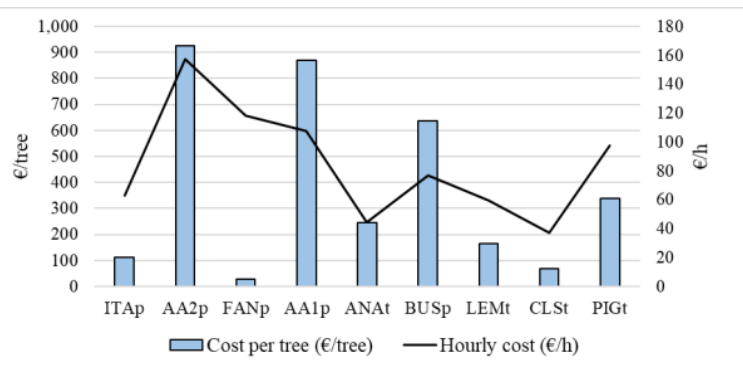

(b)

Figure 3. (a) Unitary time ( $\mathrm{h}$ tree $\left.\mathrm{e}^{-1}\right)$ and productivity $\left(\mathrm{Mg} \mathrm{h}^{-1}\right)$ of the nine felling work yards; (b) cost per tree $\left(€\right.$ tree $\left.^{-1}\right)$ and hourly cost $\left(€ \mathrm{~h}^{-1}\right)$ (the subscript " $\mathrm{p}^{\prime}$ means aerial platforms, the subscript " $\mathrm{t}^{\prime}$ means tree-climbing). 


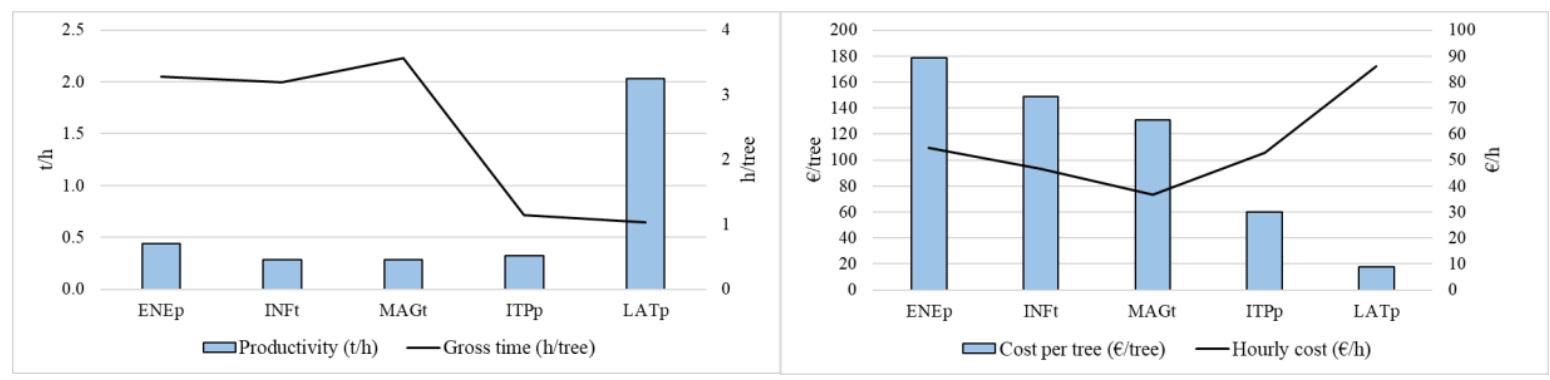

(a)

(b)

Figure 4. (a) Unitary time (h tree-1) and productivity $\left(\mathrm{Mg} \mathrm{h}^{-1}\right)$ of the five pruning work yards; (b) cost per tree $\left(€\right.$ tree $\left.^{-1}\right)$ and hourly cost $\left(€ \mathrm{~h}^{-1}\right)$ (the subscript " $\mathrm{p}$ " means aerial platforms, the subscript " $\mathrm{t}$ " means tree-climbing).

The Multiple Linear Regression (MLR) model to estimate the gross time per tree (h tree $\mathrm{e}^{-1}$ ) showed significant results (F test $=10.953$; probability $>99 \%$ ) (Fig. 5). The equation of the MLR model adopted to estimate the unitary time (GTt) was the following:

$$
\text { GTt }=-1,195-1,587 \times \text { work }-0,104 \times \text { target }+2,046 \times \text { system }+1,897 \times \text { class }
$$

The regression model individuated four independent regressors to predict the gross time: (1) "work", indicating the performed operation - felling or pruning; (2) "target," a synthetic qualitative variable, ranging from 1 to 5, indicating the easiness of the work, especially in relation to the location of the yard; (3) "system", which indicates if the work was carried out by aerial lift or tree-climbing; (5) "class", indicating 5 dimensional classes of the tree as function of the estimated residual tons of biomass $(1:<1 ; 2: 1-3 ; 2: 3-5 ; 4: 5-7 ; 5:>7 \mathrm{Mg})$.

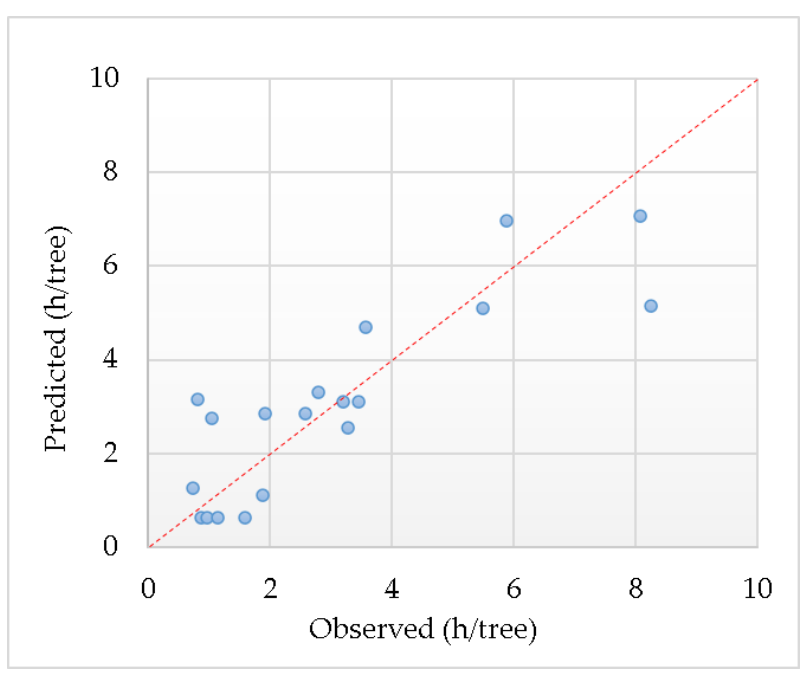

Figure 5. Predicted and observed values of gross time (h tree $\left.{ }^{-1}\right)$ on 19 analyzed trees (statistics: determination coefficient $R^{2}: 0.74$, adjusted $R^{2}: 0.67$, p-value: 0.000 ). 


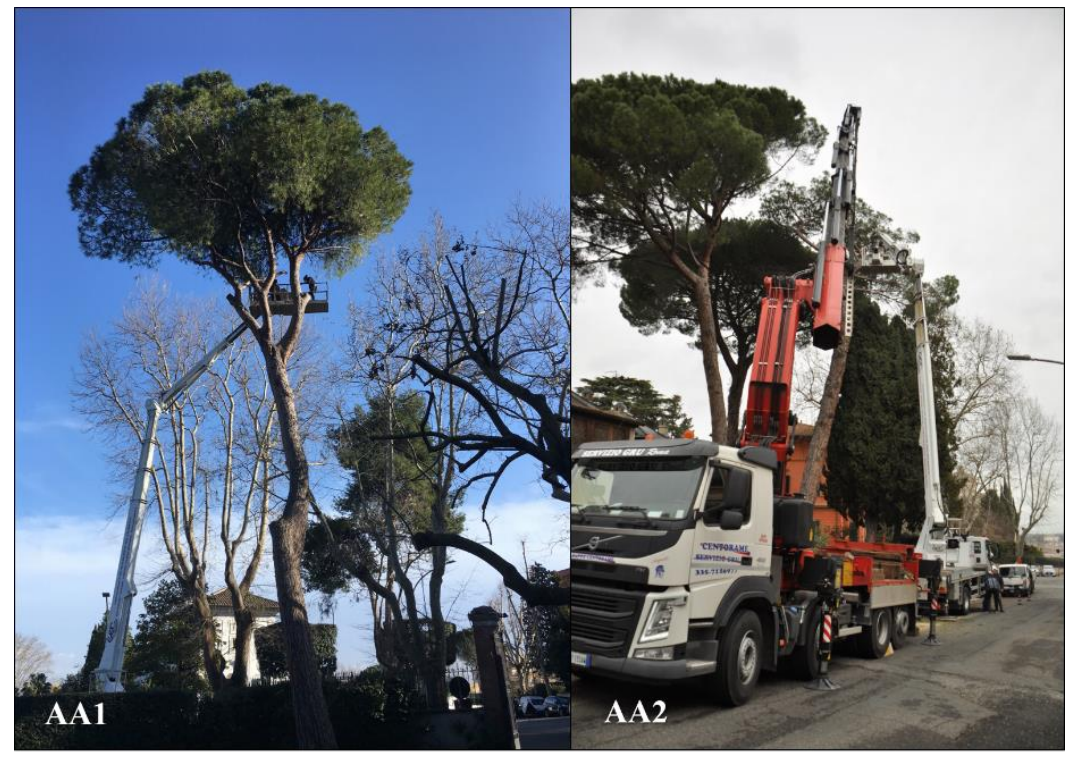

Figure 6. The felling yards AA1 and AA2. Note in the AA2 the truck mounted crane employed to descend the heaviest logs.

\section{Conclusions}

In the present study, urban trees yards of felling and pruning were studied. The research has regarded a species, Pinus pinea, that is extensively utilized as ornamental tree in cities and that has been threatened by several causes. A work time analysis was carried out from the setting of the yards to the preparation for the loading of the residual wood. Time analysis can individuate weakness points in the operations, and it contributes to study the work from a safety point of view. In the observed cases, the gross time is slightly higher when the operations are carried out by tree-climbing, both in pruning and felling (Figure 2). This seems due mainly to the "setting and stacking" operation time (Figure 1) that is generally higher for tree-climbers. Since this time element includes several operations, (preparation of the yard, dressing of the operator, preparation to ascend, transport of the cut wood to the collection and its stacking), many factors can cause the difference. However, it was observed that, in the case of tree-climber, the initial phases of the work are longer than the case with aerial lift. Moreover, since the location of tree-climber sites of work is more problematic than those of the places where an aerial lift can operate, it resulted crucial the distance from the tree and the collection point, significantly higher in tree-climbing yards than in the aerial lift ones (2 and $18 \mathrm{~m}$, respectively). Consequently, the organization of the yard should take in account the distance from the tree to the point where the wood is stacked before the loading, and the firm should take decisions to optimize this point.

The adopted MLR model, which utilizes four regressors easily evaluable before the work, has given interesting results about the prediction of the gross time per tree. However, the limited number of observed yards prevents, so far, a generalized conclusion about this point. Therefore, future studies are required, also to individuate a model capable to effectively predict the cost.

Author Contributions: The authors contributed equally to the work.

Funding: This research was funded by the Italian Ministry of Agriculture (MiPAAF) under the AGROENER project (D.D. n. 26329, 1st April 2016) - http://agroener.crea.gov.it/.

Acknowledgments: The authors are grateful to the following companies that carried out the works described in the paper: Ecologistica srl (Viterbo), Ecogeo srl (Roma), Ars Arborea sas (Guardea, TR), Il Giardino Malandrino srl (Roma), Verdeitalia srl (Roma).

Conflicts of Interest: The authors declare no conflict of interest. 


\section{References}

1. Agrimi, M.; Ciancio O. Le Pin Pignon (Pinus pinea L.). Silva mediterranea 1984. Document provisoire monographie. FAO Ed. 116 pag.

2. Comune di Roma. Bilancio arboreo 2016. www.comune.roma.it. (accessed on 25/10/2020).

3. Massari, G. L'albero urbano a Roma. Ed. Tomo, 1991. 256 pp.

4. Biocca, M.; Motta, E.; Lucatello, G.; Dallari, D. Aspects of the stability of the Italian Stone Pine (Pinus pinea L.) in Rome, Italy 2003. Atti del "Second International Symposium on Plant Health in Urban Horticulture" Berlin, Germany, August 27-29. 228-229.

5. Gasparella, L.; Tomao, A.; Agrimi, M.; Corona, P.; Portoghesi, L.; Barbati A. Italian stone pine forests under Rome's siege: learning from the past to protect their future, Landscape Research, 2017, 42, 211-222, DOI: 10.1080/01426397.2016.1228862.

6. Biocca, M.; Bortolini, L. Macchine e tecniche per il verde urbano. Realizzazione, cura e manutenzione delle aree verdi. Consiglio per la ricerca in agricoltura e l'analisi dell'economia agraria - CREA (Ed.), Roma, Italy, 2019; 234 pp. ISBN 9788833850108.

7. Vogt, J.; Hauer, R. J.; and Fischer, B. C. The costs of maintaining and not maintaining the urban forest: a review of the urban forestry and arboriculture literature. Arboriculture \& Urban Forestry 2015, 41, 293-323.

8. Mazzocchi, F.; Cecchini, M.; Monarca, D.; Colantoni, A.; Caruso, L.; Leopardi, F. An overview of risk assessment for tree climber arborists. Contemporary Engineering Sciences, 2015, 8, $1171-1177$.

9. Bortolini, L.; Cividino, S. R. S.; Gubiani, R.; Cecchini, M.; Delfanti, L. M. P.; Colantoni, A. Urban green spaces activities: A preparatory groundwork for a safety management system. Journal of Safety Research, 2016, 56, 75-82. https://doi.org/10.1016/j.jsr.2015.12.004.

10. Anderson, D. L.; Koomjian, W.; French, B.; Altenhoff, S. R.; Luce, J. Review of rope-based access methods for the forest canopy: safe and unsafe practices in published information sources and a summary of current methods. Methods in Ecology and Evolution 2015, 6, 865-872. https://doi.org/10.1111/2041-210X.12393.

11. Biocca, M.; Gallo, P.; Sperandio, G. Technical and Economic Evaluation of Urban Trees Pruning by Climbing Arborists. Lecture Notes in Civil Engineering 2020, 67, 653-660.

12. Bagagiolo, G.; Laurendi, V.; Cavallo E. Safety Improvements on Wood Chippers Currently in Use: A Study on Feasibility in the Italian Context. Agriculture 2017, 7, 98; doi:10.3390/agriculture7120098.

13. Colucci, M.; D'Antonio, P.; D'Antonio, C.; Evangelista, C. The biomasses deriving from the public parks management: an hypothesis of a city-wood-energy chain in Potenza. Proceedings of "International Conference Ragusa SHWA2010 - September 16-18, 2010 Ragusa Ibla Campus- Italy" 635-642.

14. Sperandio, G.; Fedrizzi, M.; Pagano, M.; Guerrieri, M.; Verani, S. Abbattimento di palme infestate da punteruolo rosso. Sherwood 2014, 204, 35-38.

15. Verani, S.; Sperandio, G.; Picchio, R.; Marchi, E.; Costa, C. Sustainability assessment of a self-consumption wood-energy chain on small scale for heat generation in central Italy. Energies 2015, 8, 5182-5197.

16. Li, Y.; Zhou, L.; W.; Wang, R. Z. Urban biomass and methods of estimating municipal biomass resources. Renewable and Sustainable Energy Reviews, 2017, 80, 1017-1030. https://doi.org/10.1016/j.rser.2017.05.214.

17. Raud, M.; Mitt, M.; Oja, T.; Olt, J.; Orupõld, K.; Kikas, T. The utilisation potential of urban greening waste: Tartu case study. Urban For. Urban Green. 2017, 21, 96-101. https://doi.org/10.1016/j.ufug.2016.11.014.

18. Velázquez-Martí, B.; Sajdak, M.; López-Cortés, I. Available residual biomass obtained from pruning Morus alba L. trees cultivated in urban forest. Renewable Energy 2013, 60, 27-33. https://doi.org/10.1016/j.renene.2013.04.001.

19. Miyata, E.S. Determining fixed and operating costs of logging equipment. General Technical Report NC-55. St. Paul, MN: Dept. of Agriculture, Forest Service, North Central Forest Experiment Station, MN, USA, 1980.

20. IBM Corp. IBM SPSS Statistics for Windows, Version 24.0. Armonk, NY: IBM Corp. 2016.

21. Tabacchi, G.; Di Cosmo, L.; Gasparini, P.; Morelli, S. Stima del volume e della fitomassa delle principali specie forestali italiane. Equazioni di previsione, tavole del volume e tavole della fitomassa arborea epigea. CRA, Unità di Ricerca per il Monitoraggio e la Pianificazione Forestale. Trento, Italy, 2011; 412 pp.

(C) 2020 by the authors; licensee MDPI, Basel, Switzerland. This article is an open access article distributed under the terms and conditions of the Creative Commons Attribution (CC-BY) license (http://creativecommons.org/licenses/by/4.0/). 